\title{
XLIX. Remarks on Mr. Carter's paper on the gopher-wood
}

\section{Charles T. Beke Esq.}

To cite this article: Charles T. Beke Esq. (1834) XLIX. Remarks on Mr. Carter's paper on the gopher-wood, Philosophical Magazine Series 3, 4:22, 280-282, DOI: 10.1080/14786443408648327

To link to this article: http://dx.doi.org/10.1080/14786443408648327

册 Published online: 01 Jun 2009.

Submit your article to this journal

Џ Article views: 2

Q View related articles $\asymp$ 


\section{[ 280 ]}

XLIX. Remarks on Mr. Carter's Paper on the Gopher-wood. By Charles 'T. Beke, Esq.

To the Editors of the Philosophical Magazine and Journal. Gentlemen,

I OBSERVE that my paper on the Gopher-wood of Scripture, which appeared in the Number of your Magazine for August last, has given rise to the observations upon the same subject, made by Mr. Carter in your last Number.

That gentleman justly states my argument to be, that the

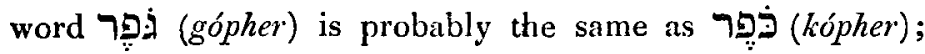
that kopher means pitch; and that consequently the wood in question would appear to be that of a pitch tree.

The first of these propositions Mr. Carter allows to be " highly probable"; but at the same time that he admits gopher to be identical with lopher, and thus agrees with me in all that I really contended for, he thinks it very questionable that the latter word means pitch, as it is rendered in the received English and all other authorized versions, for the reason, principally, that the verb רפָ (kaphár), from which ذפֵ (kopher) is plainly derived, is nowhere used in Scripture in the sense of 'to cover or daub with pitch.'

But this reasoning must surely have been adopted too hastily; for $\mathrm{Mr}$. Carter can never intend it to be his meaning that a derivative word is not to be used in a secondary sense, because the root to which it is to be traced cannot in every case have attached to it the same secondary meaning as that of its derivative*. Were it so, the use of kapher and its derivatives, in the sense of ' to purge away or pardon' (Ps. lxv. 3.); ' to atone' (Lev. iv. 35) ; ' to disannul or obliterate' (Isa. xxviii. 18.); ' a ransom' (Exorl. xxi. 30.); ' a [covered?] bason' (1 Chron. xxviii. 17.), or even 'pitch'; - -all of which meanings have plainly a direct reference to the primary signification of

* It is scarcely necessary to adduce any illustration of the consequences of opposing what is, in fact, a fundamental principle of language : one example presents itself, however, which is so very apposite, that I cannot refrain from citing it. It is in the Latin verb tegere, to cover, which besides its derivatives tegmen, tegimen and tegumen, of which the imeaning, generally, is a ' covering', whether signifying in particular a 'garment', a 'hide', a 'shade', a 'shelter', \&c., has also another derivative, namely, tegula, which word is exclusively applied to the article used for the covering of dwellings : yet because not one passage in any author can be found in which the verb legere has of itself' the particular import of 'to tile', it would certainly never be contended that, therefore, tegula does not signify a tile. 
the verb ' to cover,'-would be erroneous: and it may be added that (independently of all other objections to it,) Mr. Carter's suggestion that kopher means cypress, must, upon his own reasoning, be wholly untenable, for not one passage can be found in Scripture in which kaphar has the particular import of 'to cover with cypress'.

Indeed, if there be any word which has attached to it a fixed and unequivocal meaning, it seems to be this word kopher (Gen. vi. 14.), which, as far as my information extends, is not attempted to be rendered otherwise than by the word ' pitch', in any version of the Bible, excepting in that of Mr. Bellamy, -the authority of which version, however, I may be allowed unqualifiedly to dispute. But it is not necessary to depend solely upon the received translations for the determination of the true signification of this word, seeing that the Arabic

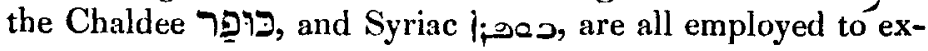
press the same word ' pitch'. Nor does the proof of its meaning rest even here; for we find the Hebrew word תירפיר

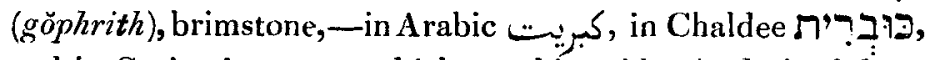
and in Syriac $\left[\Lambda_{0} 20,-\right.$ which word is evidently derived from כפֵפר in in its secondary signification of pitch, on account of the resemblance, however partial or indirect, of the one substance to the other, and not from its primary meaning ' a covering', with which brimstone cannot possibly have any connexion.

The process of the derivation of the word gophrith may be thus stated. The vegetable pitch with which Noah's ark was covered, was that substance to which the name of kopher, or gopher, was applied in the first instance: this name was afterwards (as, in fact, has been the case with its English representative ' pitch',) extended to the Asphaltus, or mineral pitch; and from the resemblance which brimstone bears to asphaltus, not only in its mineral origin, but also in the effect produced upon it by heat, the former substance thence derived its ap. pellation, as being ' a substance like gopher'.

The opinion advanced by Mr. Carter, that mineral rather than vegetable pitch was the product of the country where the ark was built, and that, in fact, the pitch obtained from wood could scarcely have been known to Noah, is founded upon the assumption that the situation of that country was in the neighbourhood of Babylon, and also that society in that early time existed in a state of infancy as regards its culture and knowledge. On the latter point I will refrain from saying more for the present, than that I apprehend the

Third Series. Vol. 4. No. 22. April 1834. 2 O 
evidence which we possess upon the subject ought to lead us to a very different conclusion; and with respect to the former assumption, I will refer to the paper " on the former extent of the Persian Gulf," which appeared in your Number for last month (February), from which, if the facts adduced in it are correct, the inference would appear to be that the ark could not possibly have been built anywhere in the neighbourhood alluded to by Mr. Carter.

I am not aware of any ground (beyond mere tradition, which is not to be depended upon,) for attributing any particular locality to Noah's antediluvian residence, excepting that, in the absence of all arguments for a contrary opinion, the most philosophical course is to assume that in the neighbourhood where the ark rested, there also it was built; in which case Armenia or the north of Mesopotamia has the greatest claim to be considered in that light.

It is not, however, intended to enter here upon the discussion of this subject, neither shall I attempt to determine to what particular species of tree the gopher-wood belonged; but agreeing as I entirely do with Mr. Carter, " that a reference to the existing productions of the climate in which the ark was built may not be irrelevant to such an inquiry," I will, in conclusion, merely remark, that the only wood which, in the present day, grows in any considerable quantities throughout the country of Armenia, from the frontiers of Persia as far as Asia Minor, is (as I have been lately informed) a species of white pine, the product of ${ }_{8}$ which, namely, pitch, is an article of great traffic among the natives : hence it would seem not unreasonable to imagine that Noah and his sons, after receiving the Divine directions, may have proceeded into the pine forests of their native country, and there

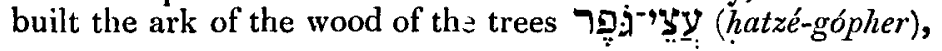
which furnished at the same time the pitch ذָּ (kópher), or (gópher), which was necessary for covering and preserving it, and for caulking it and rendering it water-tight.

March 8, 1824. I am, Gentlemen, yours, \&c.

Charles T. Beke.

L. On the Ancient and partly buried Forests of Holderness. By John Phillips, Esq., F.G.S., Professor of Geology in King's College, London*.

1. SUBTERRANEAN forests, as they are termed, abound so much on all the coasts of England, and have

Read to the Yorkshire Philosophical Society on the 4th of March 1834 ; and communicated by the Author. 